\title{
Consensus, Dissensus and Economic Ideas: The Rise and Fall of Keynesianism During the Economic Crisis
}

\author{
Henry Farrell, George Washington University \\ John Quiggin, University of Queensland
}

March 9, 2012

\section{Introduction}

"The same people who would never touch deficit spending are now tossing around billions. The switch from decades of supply-side politics all the way to a crass Keynesianism is breathtaking." Peer Steinbrück, disgruntled German Finance Minister, December 6, 2008.

As the introduction to this special issue argues, the relationship between power and ideas is at the heart of debates over international financial orders, and the cycle of stability of change that we have seen over the last hundred years. Hall 1989 documents how Keynesian ideas were widely (if not universally) accepted across advanced industrialized democracies in the wake of World War II. Ruggie 1982 famously argued that closely related ideas were crucial to the 'embedded liberalism' that ordered the international political economy until the 1980s. Both claim that the international regime was underpinned by a rough consensus over economic ideas among advanced industrialized economies. Blyth 2002 and others have documented how this consensus in turn gave way to a new neo-liberal consensus, 
based around a very different set of economic ideas. The Washington Consensus, with its emphasis on economic orthodoxy, laid the foundations for the globalization of finance over the last twenty years. We currently see contestation between the advocates of a reborn Keynesianism, and proponents of the new austerity, recapitulating teh battles between Keynesians and proponents of the 'Treasury View' in an earlier era.

Recent scholarship does not tell us whether this period of contestation will give rise to a new consensus, or instead persist. It does, however, help sharpen our understanding of where consensus over economic ideas comes from by providing more detailed micro-analyses of the relevant mechanisms. The two major lines of argument closely replicate Heclo 1974]'s distinction (as developed in Hall [1993] ) between 'puzzling' processes in which ideas emerge as a result of actors seeking to resolve collective dilemmas in an uncertain world and 'powering' - in which ideas emerge as the contingent result of contestation between actors seeking to defend their various interests. Both approaches argue that expert ideas - that is, ideas promulgated and certified by the relevant experts in a field - can have a crucial influence in shaping broader economic consensus $!^{1}$ However, they disagree both over how this expert consensus is shaped and how it has consequences.

This literature is incomplete in two important respects. First - existing theories only provide a weak account of how expert consensus itself emerges. The 'puzzling' approach builds on the core assumption of the epistemic communities account - that experts will be guided towards consensus by norms of disinterested inquiry. This is an unrealistic assumption. Although experts surely gain legitimacy from the perception that they are disinterested, this perception is usually better analyzed as a sociological construct than as a reflection of reality Barnett and Finnemore, 2004, especially in politically sensitive fields such as economics. The 'powering' approach implies that consensus is the product

\footnotetext{
${ }^{1}$ see also Ikenberry (1992)
} 
of politics, but is more comfortable analyzing the ways in which ideas help shape political coalitions, than the processes through which ideas themselves come into being.

Second - these theories emphasize consensus at the expense of dissensus. 'Puzzling' assumes that actors will be guided towards consensus through scientific norms, in which better understandings of reality prevail over weaker understandings. 'Powering' allows for some dissent (and suggests that dissenters may quietly plant seeds that might germinate into a new consensus when the prevailing one is challenged by crisis), but assumes that history consists of periods of relatively stable consensus, punctuated by defining crises. Neither has much interest in the consequences of dissensus, even though expert communities are often riven by dissent for lengthy periods of time.

In this article, we seek to remedy these blind spots in the existing literature. First, we provide a very different way to think about how consensus may arise. We deliberately skimp on the micro-processes of persuasion usually emphasized in constructivist accounts, instead highlighting the structural aspects of the cross-national networks through which experts communicate with each other. Specifically, we treat the spread of ideas within the relevant community of experts as a process of contagion, similar in many respects to the spread of an infectious disease. Second, we examine how such processes may lead to expert dissensus as well as consensus, and how this affects the power of ideas.

This allows us to meet the challenge of the introduction to this special issue, by bringing together power and ideas in theoretically novel ways. First - it allows us to identify how power relations within the expert community affect the spread of ideas. By paying attention to the ways in which this community is structured, and the topology of networked relations among actors within it, we can see how some kinds of actors are more influential than others, and hence more likely either to shape consensus or dissensus. Second, it allows us to draw conclusions about the circumstances under which expert ideas are likely to have more or 
less power. Specifically, when there is an apparent consensus (i.e. outside observers believe that there is consensus) among experts, we may expect ideas to have considerable power in shaping the options available to policy actors. When, in contrast, there is dissensus within the relevant expert community, and this dissensus maps even roughly onto divisions among policy actors, ideas will be far less likely to constrain actors, even if they are more frequently invoked as justification.

Our arguments have specific implications for the current economic crisis. Both powering and puzzling approaches have difficulty in explaining debates over economic ideas during the financial crisis. In particular, even though both approaches are crucially concerned with the rise and demise of Keynesianism in the post war era, neither is well able to explain the more recent gyrations of Keynesianism, as it surged back in the 2008-2009 period, and collapsed in 2010. As both powering and puzzling approaches would predict, consensus among expert economists played an important role in shaping actors' policy choices, where it existed. But they do not properly explain how this consensus emerged, or provide any predictions about the sources or consequences of situations where there is no consensus. As the editors of this special issue argue, we need to focus on the interplay between power and ideas if we are to understand the financial crisis of 2008-2011. If ideational consensus plays a key role in underpinning global financial orders, then we need to understand how such consensuses are generated, maintained and challenged. If we wish to understand the current politics of non-consensus, we need to move beyond the existing literature to evaluate the consequences of dissensus for economic order. We provide an account that does both, and identifies the beginnings of an alternative research program for investigating the role of ideas in international economic orders. 


\section{Networks, Contagion, and Policy Effects}

There is broad agreement in the literature that expert consensus plays an important role in shaping public debate. What produces apparent consensus among a group of policy experts? As we have already discussed, one major strand of research sees consensus as a product of technocratic 'puzzling' through complex problems, while the other emphasizes 'powering' and the ways in which ideas are shaped through political disputes and struggles.

Lindvall [2009]'s work on Keynesianism in Western European economies provides a recent and sophisticated version of the first approach. He argues that while purely political processes shape politicians' goals, politicians' understanding of the means through which they may achieve various goals is shaped by experts. Hence, expert consensus will have little impact on politicians' objectives, but that it will shape the tools that they choose to carry out those objectives. Here, expert opinion is invaluable precisely because it is disinterested and apolitical.

The second approach disagrees, drawing no particular distinction between economic policy tools and economic policy objectives. Its proponents argue that consensus over both is driven by political processes ${ }^{2}$ For example, Nelson unpublished paper argues that the spread of neo-liberal ideas to the developing world was an intensely political process, which involved both ideas over ultimate goals, and ideas over the appropriate means to reach those goals. Blyth 2002 sees both the creation and the destruction of the previous Keynesian consensus as involving political battles over how crises are defined, and hence over which solutions (which involve both 'scientific' and 'normative') elements are appropriate.In this account, economic experts necessarily play a political role in economic crises. Although their recommendations may be sugar-coated with a technocratic glaze, they will have far reaching political consequences, by defining the crisis, and by setting out

\footnotetext{
${ }^{2}$ Although see Mandelkern and Shalev (2010).
} 
proposals for how to solve it.

Both approaches have sought to explain debates over Keynesianism in previous junctures, and hence should be able to explain debates over Keynesian demand stimulation strategies in the 2008-2010 period. However, both have problems in doing this. They potentially provide prima facie plausible (albeit partly inconsistent) accounts of why policy makers embraced Keynesianism so quickly in 2008-2009. Puzzling accounts would stress how policy makers faced extraordinary uncertainty and demands from publics to do something to prevent the world economy from melting down. Keynesianism offered a diagnosis of the problem, which was supported by an apparent consensus in the relevant expert community, as well as policy tools to address it. Powering accounts would emphasize the effort of Keynesians - who had been marginalized in the previous consensus, to use the crisis as evidence supporting their understanding of economics and to help shape new coalitions.

What neither explains well is the rapid breakdown of this consensus in 2010. This breakdown poses very particular difficulties for puzzling approaches such as Lindvall's, which claim that policy makers should treat policy instruments as being neutral and technocratic, and be guided by experts in selecting over them. A profound disagreement over the appropriateness of a policy instrument for an end that all agreed on (mitigating the Great Recession) led to bitter political confrontation. Yet powering accounts too face difficulties while they can explain why it is that actors sought to put forward new ideas to shape a new consensus, they do not have any good general account of how battles over ideas take place within expert communities, as opposed to within politics more generally. These accounts place rather more emphasis on the political coalitions that mobilize around expert ideas, than the processes within the expert community through which these ideas emerge. Finally, neither approach has a very good account of the current state of prolonged dissensus, or, indeed, of lasting dissensus at all. 
We provide a better understanding of the circumstances (a) under which economic experts influence each other so as to promote consensus or dissensus and (b) under which their ideas have political influence. For the first, we treat the process of reaching 'apparent consensus' (the qualification is crucial) as a contagion process occurring across a social network. When all or nearly all individuals across the relevant network of experts have been infected by a given idea of set of ideas, such that they either favor these ideas or do not publicly oppose them, we may say that apparent consensus has been reached. When the network is not saturated by a given idea or set of ideas, but instead is characterized by warring contagions which have captured different parts of the network, we may say that there is dissensus rather than apparent consensus.

Here, we borrow from the thriving literature on diffusion and social networks. With isolated exceptions Siegel, 2009, this literature has had little impact on political science, and virtually none on international affairs $3^{3}$ This literature allows us to model the spread of beliefs, cultural representations, practices and the like as similar in broad outline to e.g. the spread of a disease across a given population. In other words, ideas may spread from individual to individual, as long as those individuals are connected through social or other ties which allow ideas to flow.

Each individual who comes into contact with a new idea has a chance of being 'infected' by it, so that she will pass it on to other individuals to whom she is connected. The likelihood of infection upon contact may vary substantially from individual to individual, depending on position in the network or other factors. When ideas become endemic across a network, the chances of infection become higher, because individuals connected to significant numbers of others in the network are likely to be exposed multiple times $4^{4}$ Hence,

\footnotetext{
${ }^{3}$ The burgeoning literature on networks in international affairs focuses primarily on network structure rather than contagion Hafner-Burton et al., 2009, Carpenter, 2007, 2010, Nexon and Wright, 2007.

${ }^{4}$ Here, we assume that diffusion depends on individual contacts, rather than a broad social 'threshold' of acceptance being reached which is sufficient to convince individuals.
} 
contagion models prompt us to think about ideas as spreading (or failing to spread) across a population as a result of processes of learning, imitation, lip-service and communication, which take place via various channels of contact and communication among individuals.

This account skimps on the underlying micro-mechanisms through which ideas spread so as to highlight how structural features of the network shape the formation of expert consensus. The shape of the social networks within which actors are embedded will have important consequences for e.g. the likelihood that ideas will become endemic across a given population, the ease with which ideas can spread to sub-populations, the degree of influence of specific actors or subgroups of actors on others and so on 5 Most simply, under most ${ }^{6}$ accounts, the more links within a network, the more likely it is in general that new ideas will spread. Highly clustered (i.e. networks where if there are three nodes, A, B, and $\mathrm{C}$, and $\mathrm{A}$ and $\mathrm{B}$, and $\mathrm{B}$ and $\mathrm{C}$ are linked to each other, there is a high probability that A will also be linked to B) will see greater likelihood of ideas spreading within a particular cluster if one node in that cluster has been infected, but lower likelihood of it ideas spreading across the network as a whole. The consequences of clustering are to some extent mediated by 'small world effects' - rapid diffusion may occur in small world networks, which combine high clustering with some linkages across clusters Watts and Strogatz, 1998]. Finally, the greater the variance in the number of links associated with nodes, the easier it will be for ideas to spread across the network. In networks where some nodes have far greater numbers of links than others (e.g. the distribution of links is powerlaw or lognormal), contagion will be easier, provided that the nodes with higher degree (those with more links) are 'infected' and pass the idea along. More plainly expressed some individuals may have much larger sets of network ties than others. These individuals

\footnotetext{
${ }^{5}$ The following leans heavily on (redacted). We are grateful to (redacted) for having shaped our thinking on this topic in crucial ways.

${ }^{6}$ But not all; see the model of cultural diffusion in Watts 2007.
} 
hence can serve either as firebreaks (if they are unusually resistant to infection) or as disseminators of ideas (if they are reasonably likely to be infected).

Taken together, these arguments suggest the following. The greater the number of links in a given social network, the easier it is for ideas to spread rapidly. The greater the variance of degree within a given network, the more marked will be the ability of nodes with high degree to block or foster apparent consensus. On average, some individuals within the network - those with many connections - will play a far more important role than others in determining which ideas succeed in generating apparent consensus, and which fail. Furthermore, the more clustered a given social network is, the more important will be role of 'stars' with high degree and cross cutting ties in spreading contagion across clusters.

Where contagion processes make a given idea or set of ideas endemic across a given network, we can say that this community has reached apparent consensus. Here, we define apparent consensus as the dominance of a given idea or related set of ideas within an expert community, such that outside observers conclude that there is widespread agreement on those ideas within the relevant community (for convenience, we use the terms 'consensus' and 'apparent consensus' interchangeably). This definition does not require that everyone within the community actually agrees with the idea or ideas in question. Urfalino treats 'apparent consensus' as a specific mode of decision-making, and notes that it may involve substantial power asymmetries allowing dominant actors to paper over fundamental disagreements. So too, the looser forms of apparent consensus that we describe are best considered as not requiring genuine unanimity, but instead the publicly visible dominance of one set of ideas, and the reluctance or inability of most experts who disagree with these ideas to make their disagreements known in a publicly obvious fashion.

Where there is no such endemic set of ideas across the network, but instead serious dis- 
agreement between different groups, who have been infected by clashing ideas, and seek to spread them to others, we can say that there is dissensus. Here, we may expect that outside observers will not conclude that there is widespread agreement across the community, but instead treat it as divided. Furthermore, we may expect less covert disagreement than in a community of apparent consensus - ceteris paribus it will be easier for experts to proclaim their disagreement with prevailing ideas if there is an alternative coalition that they can join. Thus, we can expect not only more disagreement in absolute terms, but that this disagreement will be more open, more polarized, and more visible to outside observers.

Whether there is expert consensus or expert dissensus will have important consequences for the power of economic ideas. Where there is an apparent ideational consensus among the relevant expert community, it will be far more costly to take actions inconsistent with that consensus, and easier to take actions that are consistent with it. Because social authority is vested in economic experts, actions that run against these experts' consensual ideas will be treated as less legitimate, and will be more likely to arouse opposition. Hence, expert ideas will be most likely to shape political outcomes when they are backed by an apparent consensus. Those policy makers whose preferred tools or outcomes are consonant with expert opinion will be considerably advantaged over those policy makers whose preferred tools or outcomes are not.

Alternatively, where there is dissensus within the relevant expert community, and where that dissensus roughly maps onto the different actions preferred by different policy makers, policy makers will have greater freedom of action. Rather than being constrained by a single consensus, policy makers may choose whichever set of experts seem most congenial to them, to provide a patina of expert authority for their choices. Under these circumstances, the role of experts will not be to shape debate, but to provide legitimation.

Consensus among experts over a given set of ideas does not, of course, completely con- 
strain political actors. Other factors, including e.g. coalitional dynamics, electoral considerations, relative bargaining power and unanticipated events play a crucial role in explaining behavior. Not only is it typically impossible to eliminate other causal factors that may confound the influence of ideas [Nelson and Yeo], but it is precisely in the interaction of a variety of factors that we are likely to find the most interesting causal stories Gourevitch, 1986. We explicitly do not argue that expert consensus or dissensus are the only important explanatory factors - instead, we adopt the more limited goal of showing that they mattered, and that the ways in which they mattered seem consonant with our arguments.

\section{The economics discipline as a cross-national social network}

The existing literature provides strong reason to believe that the ideas of academic economists play a key role in determining economic policy. They shape domestic policy Sikkink, 1991, and the goals and tools of international institutions [Chwieroth, 2009]. Individuals with Ph.D. level training in economics have been key vectors for the spread of neo-liberalism in the developing world. Unusually for an academic discipline, there is a strong connection between ideational debates and public policies. Highly-respected scholars may move back and forth between the academy and a small number of elite policy institutions (including most prominently the IMF, the World Bank, the OECD, and the US Treasury), continuing to engage in ideational debate in both policy and academic settings.

Understanding how this network is structured is important to understanding how ideas travel across it, and the circumstances under which consensus and dissensus may arise. Three aspects of this network are particularly important. First - to what extent is the network of economics genuinely cross-national, as opposed to being organized in relatively discrete national networks? Second - to what extent is this network skewed towards some countries rather than others? If economists working in some national systems are ceteris 
paribus more likely to be influential than economists working in others, then this is likely to have consequences for whose ideas travel, and whose do not. Third, what is the underlying topology of the network, independent of its cross-national distribution? Some network topologies are more conducive to contagion than others. Equally, some topologies are more likely to lead to inequalities of influence than others.

The evidence strongly suggests that economics is organized as a cross-national network rather than one consisting of discrete national clusters with only a few interconnections. Economic sociologists such as Fourcade 2006 provide excellent reason to believe that the economics profession forms a relatively coherent cross-national community. The field of economics is relatively densely connected, strongly internationalized, and encompasses a wide community of people in academia, national governments and international organizations.

Second, the field of economics is heavily US-centric. Sociologists and political scientists argue that international networks of economists are dominated by those with US (and to a lesser extent, UK) training [Fourcade, 2006, Nelson, unpublished paper. Cardoso et al. 2010] find that even though North American authors do not dominate the broad field of economics journals as once they did, they still account for over three quarters of the output of elite journals. While research economists in Europe and elsewhere have become more integrated over time into international networks, these networks are still dominated by the US.

Unfortunately, there is no direct evidence regarding the underlying topology of the network through which ideas and beliefs flow among economists. Gathering evidence regarding these structures would involve a massive data collection exercise. However, there is a reasonable proxy - publication patterns among economists. We may reasonably expect that patterns e.g. of authorship and co-authorship among economists will track their broader 
social and intellectual networks. Scholars will tend to co-author articles with others with whom they have reasonably strong personal and intellectual relations. By focusing on authorship patterns, we will likely lose fine-grained detail, and will surely under-estimate 'weak ties' which may also serve as vectors of influence. Even so, patterns of co-authorship will provide important information as to the underlying structures through which ideas flow within the discipline.

Goyal et al. 2006 uses article co-authorship patterns as a means of capturing the topology of the academic discipline of economics. They find that the 'connected component' among published economists - that is, the largest subset of the network for which it is possible to draw a path across the network between any two co-authoring economists within the set, covered $40 \%$ of all nodes in the network (that is; of all published economists) during the 1990s. Clustering among economists is relatively high, but so too is variance in the degree distribution, creating a 'small world' network, combining high clustering with cross-cluster links facilitating interchange across structures, are relatively common.

Goyal et al. 2006 furthermore find that the distribution of co-authorship links is strongly hierarchical, and mediated through the 'star' economists with the highest number of links (as Newman and Park 2003 show, elite interlinkages are common in social networks). For example, they find that the prominent economist Joseph Stiglitz collaborates with a large number of other economists, some of whom are other 'stars,' some of whom are not. The non-stars whom he collaborates with typically do not work with each other, or with the other 'stars' whom Stiglitz collaborates with. Nor does Stiglitz typically collaborate with the non-stars whom his 'star' co-authors collaborate with. Hence, the co-authorship network is highly hierarchical and segmented - a small elite of 'star' economists play a crucial role in connecting the disparate subgroups within the network. At least some of these findings - e.g. high variance in degree - are replicated by other indicators of networks 
of information flow among economists, such as citation networks Iglesias and Pecharroman, 2007 .

These characteristics lead us to make the following predictions. First - that contagions can spread remarkably quickly should appropriate conditions (e.g. a weakening of economists' immunity to new ideas, thanks to intellectual crisis) present themselves. Second - that the networks through which ideas diffuse among economists will involve strong cross national ties. While there may be national clusters of economists, cross-national ties between these clusters will be such that ideas can diffuse readily. Hence, economic ideas can spread internationally far more readily than across other, less internationalized, disciplines or fields. Third - that US based economists will play an especially important role in economic debate. Economists based in other national systems will pay far more attention to ideas that enjoy currency in the US than vice-versa. Fourth - that the domination of the network by a relatively small and mutually interconnected 'elite' means that 'star' economists will provide the key intellectual linkages within the discipline, usually determining which ideas are propagated, and which wither on the vine, or are confined to specific clusters.

\section{The Apparent Consensus Before the Crisis}

From roughly the mid-1980s on, the apparent consensus among economists was that tra-

ditional Keynesianism did not work. A school variously dubbed "New Classical Macroeconomics," "Rational Expectations" or, more colloquially, freshwater economics (its sources of strength were in the Great Lakes region, as opposed to saltwater economics on the East and West coasts) fundamentally reshaped macroeconomic theory in ways uncongenial to Keynesianism. This school did not entirely prevail - some of its starting assumptions proved to be untenable. Internal criticisms were reinforced by external challenges to the 
Keynesian paradigm. Keynesian economics had considerable difficulty in explaining the economic circumstances of the late 1960s and early 1970s.

The results were emphatic. Traditional Keynesianism more or less disappeared from economics syllabi. Traditional Keynesians did not disappear, but they surely found themselves beleaguered. In the (likely deliberately provocative) description of Robert Lucas, the most important pioneer of rational expectations economics:

One cannot find good, under-forty economists who identify themselves or their work as 'Keynesian'. Indeed, people even take offense if referred to as 'Keynesians'. At research seminars, people don't take Keynesian theorizing seriously anymore; the audience starts to whisper and giggle to one another (quoted in Mankiw 2006]).

David Colander reports that Keynesian economics "faded from the teaching" of economics. Colander, 2007,

These intellectual trends helped take previously unquestioned policy options off the table, as policy actors began to believe that the consensus within the field of economics had shifted decisively against Keynesianism. Important international institutions such as the IMF and the OECD, which were primarily staffed by economists, began to advise against Keynesian policy prescriptions. Martin Feldstein, sometime chairman of the Council of Economic Advisers and president of the National Bureau of Economic Research wrote a highly influential article for The Public Interest on the "retreat from Keynesian Economics," arguing that the Keynesian consensus among economists was dissolving, and doing his best to help speed this process of dissolution along as quickly as possible [Feldstein, 1981. The result of these changes, in Alan Blinder's description, was that

virtually every contemporary discussion of stabilization policy by economists 
- whether it is abstract or concrete, theoretical or practical - is about monetary policy, not fiscal policy. Blinder, 2004

Thus, by the mid-1980s, an apparent consensus had emerged among academic economists that Keynesianism did not work. However, it is important to be clear that this apparent consensus masked hidden divisions. Although few scholars explicitly advocated Keynesian policy, many (especially those who had received their graduate education in the 1980s and earlier) still adhered to Keynesian beliefs. Some of these economists occupied positions of high prestige in the field, including Paul Krugman, Alan Blinder, Joseph Stiglitz, Olivier Blanchard and the ambiguously Keynesian Greg Mankiw. More policy oriented economists at the Federal Reserve and the International Monetary Fund still used basic Keynesian tools (the IS-LM model developed by John Hicks) to guide their policy analysis 7 although their modeling efforts were more or less invisible in the broader academic literature. A few Keynesians - most notably Paul Krugman, who had a regular column in the New York Times and the prolific economics blogger and Berkeley professor Brad DeLong had established significant media platforms outside the academy, even if their dissidence on underlying theoretical issues was not especially publicly visible. Even if the debate over Keynesianism seemed dead and few prominent economists were publishing work that directly advocated Keynesian solutions, there was a significant Keynesian party hidden within the academy.

\section{The Resurgence of Keynesianism in the Crisis}

Why and how did international debates among economists shift so much in the 2008-2009 period? And what consequences did this shift have for political debates between the US and others (most particularly Germany) over how to respond to the crisis? Over an extremely

\footnotetext{
${ }^{7}$ Interview with Paul Krugman
} 
short period of time, the apparent consensus among academic economists shifted from an anti-Keynesian to a pro-Keynesian stance. Clearly, this was provoked by the economic crisis. However, as Blyth 2003 argues, structures do not come with an instruction sheet, and there were other possible interpretations of the crisis than a Keynesian one. International debates over economic policy quickly turned into a confrontation between the US, which forcefully advocated a coordinated Keynesian response, and Germany, which was equally forceful in arguing against such a response.

The Keynesian resurgence was not entirely a product of the crisis. A Keynesian analysis and associated prescriptions had already begun to emerge in expert debate in January 2008, before the crisis proper hit. Dominique Strauss-Kahn, the Managing Director of the IMF, had announced at Davos that "a new fiscal policy is probably today an accurate way to answer the crisis", prompting Larry Summers to note that "This is the first time in 25 years that the IMF managing director has called for an increase in fiscal deficits" Giles and Tett, 2008. Both Strauss-Kahn and the IMF's chief economist, Olivier Blanchard, were pragmatic Keynesians, with a theoretical bent that differed markedly from the previous consensus position at an institution notoriously fond of advocating fiscal retrenchment for countries in difficulty. However, it was only as the recession began to change into an actual crisis from September 2008 on, that Keynesianism began to really shape debate. By late 2008, economists such as Barry Eichengreen and Paul Krugman were taking to the press to make the case for aggressive coordinated fiscal policy Eichengreen, 2008.

These recommendations all represented a return to a broad Keynesian analysis of the risks faced by national economies. Under Keynesian theory, active fiscal policy may be necessary to break out of a liquidity trap, a situation in which monetary policy (tools aimed at boosting liquidity and lowering interest rates) are effectively useless. If government is willing to spend money to boost aggregate demand, it can break the economy out of this 
trap by boosting aggregate demand, and hence help the economy return to stability. However, in an open global economy, there is a clear risk that Keynesian demand stimulation strategies may boost demand for imports, limiting their domestic benefits, and creating incentives for free riding. Hence the argument for a coordinated international response, and the worries among e.g. US economists that other countries were not prepared to do what was needed to address a global crisis.

Equally significant was the failure of anti-Keynesian economists to make a politically viable case against Keynesian policy. As the IMF's chief economist, Olivier Blanchard notes, "it is interesting that the fears about higher debt and the problem of fiscal consolidation were nearly totally absent from the debate" in the first stage of the crisis 8 While Barro and Redlick 2009 did make the standard argument that Keynesian policies would be self undermining if individuals rationally anticipated the future, in opinion pieces for the Wall Street Journal, they were more or less on their own. Eventually, other anti-Keynesians, such as Eugene Fama and John H. Cochrane, both at the University of Chicago, made similar arguments. However, their arguments were swiftly greeted with gleefully detailed counter-arguments from Krugman, DeLong and others, which were usually published in more visible places than the original critique. Their counter-efforts were furthermore hampered because they were dilatory (with the exception of Barro, they began to publish their counter-arguments in early 2009, after the advanced industrial democracies had already committed to Keynesian solutions) and because they were embroiled in larger controversies surrounding the economics profession $\square^{9}$ Finally, few were very used to direct engagement in policy debates. As described by Paul Krugman, a participant in these debates who was otherwise not noted for sympathy towards his intellectual opponents:

\footnotetext{
${ }^{8}$ Interview with Olivier Blanchard, April 2011.

${ }^{9}$ Fama was a tireless proponents of the "efficient markets" perspective which had unsurprisingly lost much of its luster in the wake of the crisis of financial markets in 2008.
} 
Freshwater economists were not that keyed into policy. ... It's been a selection process to some extent. ... Initially, Barro was there, but on the domestic side, you were talking about people who were not economists, or who were Austrians [i.e. subscribers to a minority approach in economic theory and libertarian philosophy associated with von Mises and Hayek]. ... if your view about policy is mostly that the government shouldn't do it, it's possible to write two articles a month saying that, and if you are Milton Friedman you can carry it off and get a large audience, but ... it's harder than it is to be weighing in on stuff the government should be doing. 10

The result was that these criticisms were isolated and marginalized. As Vice-President Joseph Biden's economic adviser, Jared Bernstein describes it,

I don't recall a lot of criticisms back in late 08-09 that were sticking in any way. You are always going to get that craziness on the back pages of the Wall Street Journal but I don't think many people take that seriously 11

Republicans, who were vehemently opposed to the stimulus package, based their counterarguments on apparent common sense claims about how government needed to tighten its belt, rather than on economic theory.

Even more important was the conversion of many prominent pro-free market economists to advocates of stimulus. Richard Posner's public conversion to Keynesianism in the pages of The New Republic gathered significant public attention [Posner, 2009]. But far more visible within the profession was the Damascene conversion of Martin Feldstein, one of the most important anti-Keynesians in the economic debates of the 1980s. As recently as 2007, Feldstein had still excoriated the malign public consequences of Keynesian ideas Feldstein,

\footnotetext{
${ }^{10}$ Interview with Paul Krugman, April 2011

${ }^{11}$ Interview with Jared Bernstein, July 2011
} 
2007. When Feldstein began to make the case for activist fiscal policy in ever-more public fora during late 2008, it had a pronounced effect on debate among on his colleagues, helping to create the impression of a complete upheaval in the profession [Uchitelle, 2009.

All this led to the appearance of a new apparent consensus among expert economists that fiscal stimulus was the appropriate tool to deal with the recession. The new consensus quickly reshaped opinion among economic policy makers in international institutions with close ties to the research community, such as the IMF. On November 15 2008, Dominique Strauss-Kahn proposed a global fiscal stimulus program to the G-20, suggesting a stimulus of $2 \%$ of world GDP was necessary to help maintain growth. What was remarkable was not so much Strauss-Kahn's proposal, as the nearly complete absence of dissent within the IMF, an institution which had until recently been associated with very different economic ideas. As described by Blanchard, there was:

incredibly little debate within the institution, relative to some of things such as the debate we had on capital controls, which had been gigantic. ... There was basically no debate ... if the troops don't like it in this institution, things don't happen. Having the general in the corner is not enough. ... I don't know if everyone loved it, but basically the troops just went along. 12

The European Central Bank was far more skeptical about the benefits of fiscal stimulus. In speeches and press briefings, ECB President Jean-Claude Trichet and his senior colleagues repeatedly stressed the need to observe EU rules on deficit reduction, and for weaker states to return to fiscal consolidation as quickly as possible. However, they systematically declined to criticize Keynesian policies and the Keynesian approach as such. As described by a senior ECB official,

\footnotetext{
${ }^{12}$ Interview with Olivier Blanchard, April 2011.
} 
At the time, we were cautious in saying well, there may be some in a better position fiscally, notably Germany and a couple of others, where we we wouldn't necessarily object, but there were others who were in no position to open the purse and lavishly spend all sorts of discretionary spending programs ${ }^{13}$

While ECB officials were privately unconvinced by the logic of Keynesian demand stimulation, they refrained from openly expressing their disquiet. Hence, the expert consensus among economists over the benefits of Keynesianism was not only the result of prominent economists with Keynesian leanings finding their voice, and former prominent antiKeynesians experiencing Damascene conversions. It was also supported by the reticence of those who disagreed with the new consensus, sometimes vigorously, yet found it impolitic or inopportune to express their doubts openly.

This apparent cascade in changing beliefs also had consequences for politicians, who were initially confused about the crisis, and entirely uncertain of what to do. Before the crisis, policy makers in the advanced industrialized democracies had largely abandoned activist fiscal policy. While a few governments had experimented occasionally in demand management strategies, most prominently Japan in the early 1990s, their efforts were modest and swiftly abandoned. The dominant approach to macroeconomic policy was based on the assumption that an independent central bank, adjusting short-term interest rates in line with a 'Taylor rule,' could manage the economy in such a way as to achieve both stable inflation and reasonably steady economic growth. Active fiscal policy could not improve on this outcome, and would effectively be neutralised by offsetting adjustments to monetary policy. The "Great Moderation" (a general reduction in the volatility of output, prices and employment beginning in the 1980s) was seen as the happy outcome of this policy framework.

\footnotetext{
${ }^{13}$ Interview with senior ECB official, March 2011
} 
Policy-makers' main initial concern was to deal with the risk of collapse across the financial sectors of advanced industrialized countries. They quickly realized that these problems had broader economic repercussions and began to supplement direct intervention in the financial sector (bank takeovers, acquiring bad loans etc) with monetary policy (quantitative easing; a coordinated lowering of interest rates across large countries). However, governments quickly came to believe that monetary policy was insufficient on its own to help the real economy.

In large part because prominent economists shifted their position, politicians started to identify the economic crisis as involving a crisis of demand. This presented little political difficulty within the US government; the incoming administration was already convinced of the need for economic stimulus, and had begun to prepare the ground for a major stimulus package during the transition period. The disputes within President Obama's team were not about whether there should be a stimulus, but about how big that stimulus should be [Suskind, 2011, , p.154] p.154. Larry Summers, the head of the National Economic Council and Christina Romer, head of the Council of Economic Adviser, were both academic economists, and played a key (if sometimes quarrelsome) role in pushing for a stimulus package, persuading political advisers such as David Axelrod that "if we didn't act quickly to replace the output we were losing, unemployment could skyrocket." Lizza, 2009

The impact of economists on European debates was less direct, but equally important. As described by one important participant in European policy debates:

"The economists were in agreement in Europe to a large degree and the politicians were more reluctant, more uncertain because this was so much of a change compared to the usual way, the usual priorities. They were slower to be convinced. ... I think that what political leaders got from the economists was that people traditionally opposed to fiscal stimulus and fiscal deficits ... suddenly 
had a different view. That impressed the politicians ${ }^{14}$

By advocating straightforward Keynesian remedies to mitigate the crisis, economists shifted the center of gravity of public debate so as to make it difficult for governments (who wished to be seen responding to the crisis) to avoid some form of fiscal stimulus. Governments began to engage, individually and in concert, in fiscal policies aimed at boosting demand through direct government spending. The beginning came in November 2008, when the UK announced a UKP 20 billion package, justifying their intervention in advance with explicitly Keynesian arguments 15 and China more or less simultaneously announced a large boost in domestic spending [Skidelsky, 2009.

The US took a little longer, in large part because of the political calendar (the election took place in November 2008, but the new administration was not in place until January 2009). Incoming administration officials were also deeply concerned about the need to coordinate an across-the-board stimulus among advanced industrialized economies, with particular reference to European Union countries. For the most part, they encountered little resistance. As a result of debates among European economists (who were strongly influenced by their US peers), several European countries too had come to the conclusion that a robust fiscal stimulus was needed to avert crisis. European economists involved in these debates had closely followed the arguments that were taking place among elite American economists within the blogosphere and via The New York Times and The Financial Times ${ }^{16}$ These were supplemented by a more specific set of cross-Europe debates on the website VoxEU (which published short articles and research summaries in the field of economics, and quickly became a major site for argument over how best to respond to the crisis), with some US participation from economists such as Barry Eichengreen. The

\footnotetext{
${ }^{14}$ Interview with Jean Pisani-Ferry, November 2010

15 See e.g. Patrick Hennessy, "Alistair Darling turns to Keynes as he looks to spend his way out of recession," Daily Telegraph October 182008.

${ }^{16}$ Interview with Jean Pisani-Ferry.
} 
European Commission, which had been largely excluded from the debate on bank rescues, seized upon a coordinated stimulus as a way to demonstrate its relevance to the crisis, and over a very short period of time prepared a plan, under which each EU member state would commit to a stimulus package of $1 \%$ of GDP, which was quickly accepted by the Council of member states. The Commission's Director-General for economic and financial affairs, Klaus Regling, who had described Keynesians in a previous recession as "like rats coming out of a wall" found himself to his own surprise agreeing that fiscal stimulus was the appropriate response (interview with Jean Pisani-Ferry).

However, one key group of actors were highly skeptical about Keynesianism - German policy makers. Both conservatives (the CDU) and social democrats (the SPD) remained strongly opposed to any substantial stimulus program. In part this antipathy to stimulus stemmed from a pre-existing institutionalized hostility to Keynesianism. In Allen [2005]'s description, German monetary policy has

consistently resisted international efforts to secure a Keynesian-style reflation, whether in the context of their domestic economy or as the strongest economy in the European Union, Keynesian policies were popular only for a brief period during the Grand Coalition (1966-69) and the early ears of centerleft government (1969-74) under Willy Brandt. Even in the wake of the slow growth in both Germany and the EU during the 1990s, the Red-Green government of Gerhard Schroeder has not encouraged aggressive economic stimulus since taking office in late 1998. In fact, Schroeder dismissed from his cabinet in early 1999 the one figure, finance minister Oskar Lafontaine, who was urging just such economic stimulus.

Rather than worrying about the instability of the private economy, German 'ordoliberals' emphasized the role that private sector actors could play in coordinating and organizing 
capitalism. German economic debates in the 1990s and 2000s mostly involved ordoliberals arguing with neo-liberals, who were opposed to Germany's supply-side interventions and inter-firm coordination. Facing into the crisis, German politicians - primed by an antiinflation consensus among both economists and voters, were strongly opposed to activist fiscal policy.

However, Germany was also less badly affected in the initial stages of the crisis than most other European countries 17 German export markets in China and the developing world seemed initially not to have been badly affected. Equally, the origins of the crisis in dubious banking and financial market practices helped play to German preconceptions that countries with lax regulation, such as the US, fully deserved to reap the whirlwind that they had created, while more frugal and careful countries took shelter from the storm. Germany's long-term hostility to stimulus policy, and more particular complacency about the economic crisis led senior German politicians in both the SPD (Social Democrats) and CDU (Christian Democrats) to vigorously oppose any substantial fiscal stimulus.

Initially, the pressure on Germany to introduce a stimulus were largely external, emanating both from the European Union and the US. Both the United States and the United Kingdom were at the forefront of efforts to coordinate fiscal policies among the world's major economies so as to boost global demand. Gordon Brown sought to get member states to agree to a common stimulus, while the European Commission sought to get Germany to commit to spend $1 \%$ of GDP to boost aggregate demand in advance of the European Council summit in December 2008.

Germany was strongly opposed to these initiatives Newman, 2010. Steinbrück, the SPD Finance minister had tried to scotch any EU level initiative in early September,

\footnotetext{
${ }^{17}$ It is important to note that this is far from a sufficient explanation of Germany's policy stance. Australia too seemed at first less affected by the crisis, but introduced a large stimulus package before the economic indicators turned sour. Discussion with Australian Treasury Official, February, 2011.
} 
claiming that "Every country is responsible for itself ... it makes no sense to burn money." 18 He continued to oppose any European initiative, employing increasingly inflammatory language as time went on. When it became clear that other member states were likely to support the Commission's proposal, the German government grudgingly announced that this was acceptable - as long as previously agreed initiatives counted toward the requirement. Germany indeed announced a 20 billion euro program, which it claimed should be sufficient under the EU guidelines. However, the proposal attracted international controversy when it became clear that it largely consisted of government spending measures that had already been announced.

Persistent external pressures combined with increasing dissent from within Germany, and in particular from elite German economists. Economists play an unusually prominent and independent role in German policy debates, through the elite "Council of Economic Experts" (Sachsverständigenrat) formed in 1963 to ensure that the country's most prominent economists had formal input into German policymaking. In contrast to similar-seeming institutions in the US (the Council of Economic Advisors) and elsewhere, the Council is not formally a part of government, is non-partisan, and has considerable independent political clout. It is made up of five prominent academic economists, who are typically directly involved in international debates over economic theory (their previous employment profiles involved a high degree of international experience at English speaking universities and international institutions such as the IMF). Each year, the Council issues a report on the economy with associated policy prescriptions, which the government is obliged to publish in a short space of time. The Council's pronouncements receive extensive media coverage, and can have substantial consequences for politicians. From the early 1970s on, the Council had been strongly anti-Keynesian. The Council had pushed strongly for

\footnotetext{
${ }^{18}$ Quoted at http://www.aljazeera.com/news/europe/2008/09/2008912154850729177.html
} 
the constitutional strictures on deficit spending at the beginning of the recession. After vehement internal discussions, they did an about turn, issuing a statement finding that the initial fiscal stimulus was inadequate, and that a much stronger stimulus was needed (Sachverständigenrat 2008). This volte face was part of a remarkable turnaround among German academic economists more generally. As described by one German economist:

all of the important voices in the German economic profession are now calling for a large stimulus package, passed as quickly as possible. Not only the leading research institutes have demanded government investment and tax cuts to be pulled forward, also the Sachverständigenrat ... has asked for fiscal stimulus in its recently published annual [expert report]. ... the recent call for fiscal stimulus by leading German economists comes as some surprise. Over the past decade or so the leading research institutes, basically all leading German academic economists and also the Sachverständigenrat have consistently argued against Keynesian fiscal policy. Moreover, they have not brought forward that fiscal stimulus was not necessary (as would have been true for a boom year such as 2006), but they have usually argued that fiscal policy CANNOT work for principal theoretical considerations. Dullien, 2008

Anti-Keynesians had a very different normative interpretation of the shift, but a similar evaluation of the magnitude of the shift itself, and of the close relationship between the change in the Sachsverständigenrat's position, and a broader change among German academic economists Germi, 2009]. In debate with Bert Rürup (the head of the Council of Economic Experts) the prominent economist Stefan Homburg lamented that:

you (Rürup) and the Council of Economic Experts have told us over the years that stimulus programs do not work. You even say this in your current 
report! In a period of high unemployment, the Red-Green coalition did not launch any stimulus program, as it knew this would be fruitless ... we make ourselves hard to believe as economists when we fantasize, without any secure evidence about the worst crisis of all time, and then drag up recipes from the cellar that we held to be false last year. I simply cannot understand how so so many economics professors have done a complete about face [diametral ihre Position ändern]. Have they all gone crazy? [my translation] Von Neubacher and Sauga, 2009

In interview, Homburg elaborated further:

By and large, Germany followed the international mainstream, set forth by [the] US and UK.... I think [that the reason German professors 'all went crazy'] is due to "social contagion," as Robert Shiller calls it. I was a bit angry, admittedly, because I think scientists should follow a less emotional mode.

Economists were not the only critics of the German government's animus against Keynesianism. Other actors within Germany - most notably large firms and unions - started to push for a stronger stimulus. Nonetheless, there is strong prima facie evidence that the Council of Economic Experts' report, combined with the more general about-turn among economists, generated strong pressure on the government, not least because of the government's furious response. The leader of the SPD's Parliamentary Party condemned the Council of Economic Experts as "incompetent" and "surplus to requirements," claiming that these "so-called wise men mostly produce hot air," and proposing the institution's abolition. The Minister for the Environment claimed that the Council had, in the space of a few weeks, "turned 180 degrees. They used to to tell us to concentrate on fiscal consolidation above everything else, but now suddenly this is worthless." Rundschau. German 
Chancellor Angela Merkel felt it necessary specifically to make an attack on economic expertise and deficit spending one of the core arguments of her keynote address in December 2008 to the CDU party convention, calling for it to be replaced by good German household economics.

[The root of the crisis] is quite simple. One should simply have asked a Swabian housewife, here in Stuttgart, in Baden-Württemberg. She would have provided us with a short, simple, and entirely correct piece of life-wisdom: that we cannot live beyond our means. This is the core of the crisis. ... Then why is the world in this difficult place? Well, we have too often put our trust in experts that were not really experts. Perhaps we did not know then that they were not experts, but we know it today. When we come together now to think about how one should answer these new global questions, we should put less faith in self-proclaimed experts, and instead follow one principle: the principle of common sense! Merkel, 2008

"Common sense" - which happily coincided with the principles of ordoliberalism and the social market economy - did not preclude needed infrastructural investments, but it did rule out short term fiscal stimulus.

Thus I say: Germans can rely on a government that is responsible and prudent, and - when necessary - can act at lightning speed. But I also say: we will not participate in a competition to outdo ever newer proposals, a senseless competition of billions. We will not have it; I will not have it; in times such as these we are answerable to the taxpayer of today and the taxpayer of the future. Merkel, 2008,

Merkel's speech went in lockstep with increasingly vituperative comments from Steinbrück 
in the leadup to the European summit. After Germany was excluded from an informal planning meeting hosted by Gordon Brown, Steinbrück gave a Newsweek interview, where he described Britain's stimulus as 'crass Keynesianism' which did not 'even pass an economic test,' and which would 'raise Britain's debt to a level that will take a whole generation to work off.' The UK responded by noting "a broad international consensus that a fiscal stimulus is now the right step for the economy."

Even as Steinbrück was making belligerent statements on the European stage, his own officials were quietly preparing proposals for a second stimulus package. By the time that the summit was held, Merkel had begun to moderate her position, accepting that Germany, as Europe's biggest economy, had a "responsibility" to provide its share of the stimulus package. The European Summit closed with broad agreement on an EU-wide economic stimulus of around 200 billion euro (170 billion of which would be spent by member states), without specifying the particular contributions of individual countries to that total, or indeed providing any timeline. In January 2009, the German government announced a second - and much more substantive - fiscal stimulus of 50 billion euro. In order to finance both the stimulus and regular government spending, the government announced in March that it was going to sell 346 billion euro of government debt - the largest such sale since World War II. Although Germany successfully shrugged off arguments for a further stimulus, arguing that an improvement in economic conditions rendered such a stimulus unnecessary, it nonetheless had to undertake a major - and quite embarrassing - reversal of course.

In short, the first stage of international debate following the international crisis provides strong support for our arguments about how expert consensus comes into being, and how it may shape the broader policy consensus. Debates among economists in Europe and the US were structured in the ways that one might have expected. Densely-woven cross- 
national connections meant that the debate over Keynesian demand stimulation strategies was genuinely international. Economists were able to follow it through a variety of sources. However, it was also heavily lop-sided in favor of the English speaking world (Interview with senior ECB official), and in particular, the US. US economists enjoyed a far greater audience in Europe than European economists in the US. 'Star' economists, especially those who combined a substantial reputation within the field with a broader public audience played a crucial role in promoting the revived Keynesian consensus. On the one hand, Keynesians such as Paul Krugman were better able to engage in wider controversy than their likely adversaries. On the other, the defection of Martin Feldstein suggested compellingly that the anti-Keynesian consensus of the previous two decades was crumbling. Keynesianism spread contagiously throughout the research community. This is not to say that all parts of the research community were equally affected. As the next section makes clear, some anti-Keynesians were completely unconvinced. However, the few prominent public skeptics felt beleaguered, while other dissenters either failed to gain sufficient prominence for their disagreement, or decided to keep it to themselves. Even in Germany, long characterized by an anti-Keynesian consensus, the economics community shifted radically towards a Keynesian position.

Even if this consensus was only an apparent one - it contained within itself many pockets of quiet dissent - it nonetheless had important political consequences. Policy makers whose preferred actions aligned with the consensus had a much easier time defending their proposals than policy makers who did not. On the one hand, the consensus legitimated US administration arguments for a stimulus coordinated across the major industrial economies. On the other, it created considerable international and domestic difficulties for the German government, which would have preferred to deviate from this consensus. Germany's decision finally to acquiesce to the consensus and adopt a very expensive stimulus plan, 
despite continued doubts, provides significant evidence in favor of our arguments.

To be clear, expert consensus alone does not explain Germany's volte-face. Other factors, including forthcoming federal elections and pressure from domestic interest groups intersected with the expert opinion of economists. Yet, without the frame offered by expert consensus, political groups would have had great difficulty in articulating their demands and coalescing around them Blyth 2002. What reaction there was would have almost certainly been piecemeal. Furthermore, the very strong reaction of the German government to expert opinion, especially as formulated by the Council of Economic Experts, shows that this opinion was important to them. Politicians usually do not expend significant resources fending off challenges that they think irrelevant.

\section{Backlash - Austerity and Keynesianism in 2010}

The Keynesian revival was relatively short-lived. The Keynesian revival saw its peak in early 2009. By mid-2010, Keynesians such as Brad DeLong were lamenting that they had lost the war, apparently irretrievably DeLong, 2010]. What had happened in the interim? And why was the outcome so different from that of a little more than a year previously?

Part of the answer lay in the lurking crisis of government debt. By early 2010, the cost of the bailout, and the likelihood of further banking failures, had begun to threaten the solvency of a few beleaguered governments. Some peripheral countries such as Iceland and the Baltic states had already experienced sovereign debt crises. Governments in these countries lacked the resources to rescue their failed banking sectors, and were forced to adopt austerity policies that exacerbated the recession. The economic impact of the crisis in these countries was comparable to that of the Great Depression. Nonetheless, these countries' parlous condition initially seemed to have no greater implications for the global economy. They were not big enough to pose a significant threat. 
What these failures did was to provide rhetorical fodder for an already-existing set of arguments on how and when to make a transition from Keynesian fiscal stimulus to more normal patterns of macroeconomic management, and, where necessary, to some degree of fiscal retrenchment. In principle, both Keynesians and non-Keynesians were in agreement on the need to make this transition. In contrast to the 'Keynesian' policy synthesis of the 1960s and 1970s, under which demand management was used to pursue a variety of goals, latter-day Keynesians mostly saw fiscal stimulus as a means of dealing with economic shocks. Keynes himself had laid a strong emphasis on the need to accumulate fiscal surpluses during good years, so as to provide more room to stimulate the economy during bad times. Blanchard and two colleagues sought to make the case for just such a moderate Keynesianism in a widely-circulated OECD paper Blanchard et al., 2010]. Others, who had been less convinced of the merits of Keynesianism in the first place, at least agreed that a return to normal times would be a good thing.

However, there was vigorous disagreement among economists about when such a transition should take place. Alberto Alesina, an Italian expatriate economist at Harvard, argued strongly for an immediate retrenchment, suggesting that history showed that fiscal retrenchment could in fact enhance countries' growth prospects by improving investor confidence Alesina and Ardagna, 2009. Others such as Paul Krugman strongly disagreed, arguing that none of the cases referred to by Alesina and others provided good evidence of such an effect. Instead, they argued that states needed to avoid imperiling a fragile recovery by moving too precipitately from fiscal stimulus to retrenchment. Nonetheless, the debate among elite economists was nowhere nearly as one-sided as in 2008-2009. Important skeptics of Keynesianism were more willing to go on the record. For example, John Taylor, who in the early days of the crisis had sought to promote tax cuts as a more effective form of stimulus, repeatedly argued the case that the US stimulus had not worked. 
Nor were the criticisms confined to anti-Keynesians. As time went, left leaning economists such as Jeffrey Sachs, and economists respected by both pro- and anti- Keynesians such as Kenneth Rogoff began to call for retrenchment. Keynesians could surely argue against these economists, and they did. But they could not easily dismiss them as ideologically biased or fundamentally inept.

Thus, an apparent consensus among economists - that Keynesian measures were necessary and urgent - began to give way to a visibly two-sided debate over how and when to move back towards fiscal balance. Moreover, some economists sought strategically to widen the debate so as to discredit fiscal policy more generally. The European Central Bank had taken a back seat in debates about fiscal policy during the early stages of the crisis, correctly sensing that it was not a politically opportune time to press member to observe the fiscal strictures of Economic and Monetary Union. However, as the crisis receded, Bank officials used arguments about the timing of retrenchment to reassert their authority.

The extent to which the euro area fiscal response to the crisis has been shaped by the EMU architecture, and in particular the European fiscal rules, is not easy to gauge. One could argue that the answer is "not much". ... Obviously, there has been no concerted decision to keep Maastricht deficit and debt levels within the respective ceilings of $3 \%$ and $60 \%$ of gross domestic product, regardless of the economic circumstances. If we turn the clock back to autumn 2008, it was already obvious that most countries were heading towards "excessive" government deficits in the sense of the Treaty, if not in 2008, then certainly in 2009. Yet most euro area governments went ahead with fiscal stimulus anyway. More generally, the high fiscal deficits that have emerged in almost all industrialized countries over the past year seem incongruous with the $3 \%$ deficit limit of the Maastricht Treaty and the Stability and Growth Pact. Manuel, 2010] 
Over late 2009 and early 2010, the European Central Bank had became ever more insistent on the need for European countries to return to normal patterns of spending, and in particular for members of Economic and Monetary Union to make a speedy transition back to compliance with the requirements of the Stability and Growth Pact. Bank officials were increasingly comfortable in arguing against Keynesian fiscal stimulus, and in favor of an alternative approach based on shoring up market and consumer confidence.

we started to change tune and say "well, Keynesian multipliers are not the only thing to look at, there are also so-called confidence effects. ... the Ricardian effect ... will restrain consumption rates today which will mean that you negate the whole effect you had in mind. And vice-versa, if you can prove today that you are fiscally responsible, consumers will know that there will be no further tax increases coming, and might refrain from cautionary savings, which will help you further on the real side." ... There has been a great paper by John Taylor at the time that looks at discretionary fiscal expansion programs in the US over 50-60 years, and found their effects to be at best ambiguous and at worst actually harmful. ...We've been doing the econometrics of this for decades now - we have come to some sort of consensus which basically went out of the window within weeks. I don't think it ever really went out of the window in the ECB.

Such claims were supported by officials of the European Commission, which began to argue against further fiscal stimulus, and in favor of initiatives (which would not uncoincidentally expand the Commission's competences) to support fiscal rectitude in the member states.

The arguments of economists at the European Central Bank and elsewhere provided considerable comfort to Germany. The ECB's emphasis on fiscal rectitude resonated strongly 
with German preferences (this was unsurprising; the European Central Bank's founding principles closely reflected German priorities). Germany and the European Central Bank both resisted pressure from the US during Spring 2010 to continue with laxer fiscal policy, arguing instead for a rapid consolidation.

These debates were brought to a head by the economic crisis in Greece. During the 1990s, Greek governments had nominally complied with the euro convergence targets, which required them to reduce budget deficits to less than 3 per cent of GDP, and public debt to less than 60 per cent. In reality however, they had engaged in a variety of subterfuges and expedients to hide the true extent of their debt. When a new Greek government began to clean its house, and it became clearer exactly how indebted Greece was, markets began to panic. Initially, the German government and others were hesitant about tackling the Greek problem, for reasons that included unwillingness by Germany to foot the likely bill, given important forthcoming state level elections, the 'anti-bailout' clause of the Maastricht Treaty and the complete absence of any mechanism for dealing with these kinds of disorder (the drafters of Maastricht feared that emergency provisions might signal lack of confidence in the durability of economic and monetary union), and EU reluctance to have IMF involvement. Only after the US (which feared a renewed collapse of confidence on world markets) pressed the EU, did member states agree on an emergency mechanism with access to approximately $\$ 500$ billion euro, together with market interventions by the European Central Bank.

The consequences of this continued and self-ramifying crisis for EU politics are important but complex. Its consequences for debates about fiscal policy in 2010 were rather more straightforward. In addition to providing impetus for a new set of institutional reforms aimed at preventing fiscal crises in EMU member states, it provided a strong set of rhetorical arguments for Germany, the European Central Bank, and other actors who 
advocated fiscal retrenchment. The ECB's president Jean-Claude Trichet berated EMU member states in private for their persistent fiscal irresponsibility in the past, and informed them that they had little choice but to adhere rigidly to the rules if they wished to avoid future crises. He also began to take a much stronger position in public debate. In an op-ed for the Financial Times which the newspaper described on its own front page as 'strident,' Trichet built on what he described as an existing consensus for retrenchment and sought to push it radically more quickly [Trichet, 2010].

[t]here is a strong unity of purpose among the world's policymakers to address our fiscal fragilities. It is reassuring that the consensus on the need for credible fiscal exit strategies ... is very broad. But the timing remains disputed. ... We have to avoid an asymmetry between bold, if justified, loosening and unduly hesitant retrenchment. ... With hindsight, we see how unfortunate was the oversimplified message of fiscal stimulus given to all industrial economies under the motto: "stimulate", "activate", "spend"! A large number fortunately had room for maneuver; others had little room; and some had no room at all and should have already started to consolidate. Specific strategies should always be tailored to individual economies. But there is little doubt that the need to implement a credible medium-term fiscal consolidation strategy is valid for all countries now.

The collapse of market confidence in Greece was interpreted as a parable of the risks of fiscal profligacy. States which got themselves into serious fiscal difficulties risked collapse in market confidence and perhaps indeed utter ruin. Germany's analysis of the 2008-2009 crisis as a crisis of fiscal profligacy and bad debt was reinforced by the argument that markets would brutally punish states which did not move immediately (and preferably irrevocably) towards fiscal austerity. 
As with many strong claims made during the 2008-2010 period, the empirical evidence was muddy. On the one hand, it was clear that countries which found themselves in genuinely unsustainable positions would be likely to end up in crisis as a result of an inability to raise international debt. On the other, there was also evidence from the 1990s that markets had concerns about political as well as fiscal unsustainability - that is, they might fear that countries which sought to impose swingeing cutbacks on their populations would be unable to sustain them because of their political unpopularity. Annoyingly, markets seemed willing to reward both the United States, which was rapidly building up debt and Germany, which was still winding down its fiscal stimulus, but had signaled its move to constitutional "brakes" on future debt, with low bond yields. As the economist Dani Rodrik described it:

If you want to keep borrowing money, you need to convince your lender that you can repay. That much is clear. But in times of crisis, market confidence ...turns into what philosophers call a "social construction" - something that is real only because we believe it to be. For, if economic logic were clear-cut, governments wouldn't have to justify what they do on the basis of market confidence. It would be evident which policies work and which do not, and pursuing the "right" policies would be the surest way to restore confidence. The pursuit of market confidence would be superfluous. ... it would be nice if markets would clarify what they mean by "confidence" so that we would all know what we are really dealing with. Of course, "markets" are unlikely to do any such thing. This is not just because markets comprise a multitude of investors and speculators who are unlikely ever to get together to publish a "party program," but more fundamentally because markets have little clue themselves. 
Nonetheless, the rhetorical claim that markets 'wanted' fiscal austerity proved to be a compelling one. It fed into traditional tropes among economists, who were accustomed as a profession to lecturing governments at great and sometimes tedious length about the important disciplining role of markets. It also provided a rhetorical justification for cutbacks that (in some cases at least) governments wished to impose in any event. For example, the incoming Conservative/Liberal Democrat government in Britain, which had a somewhat high debt-to-GDP ratio, but no apparent difficulties in raising money on international markets, was able to use fears of collapsed credibility to introduce savage cutbacks to state spending that would otherwise likely have been politically impossible.

In contrast to the earlier debates on Keynesian spending, Germany did not find itself stymied by its divergence from the intellectual consensus. There was no such intellectual consensus - instead there was a debate between those advocating (on the basis of economic reasoning) continued fiscal stimulus, and those advocating (on the basis of economic reasoning) various flavors of economic austerity. When Paul Krugman harshly criticized Germany's emphasis on austerity in his New York Times column and in an interview with Handelsblatt, the head of the Sachverständigenrat responded by arguing that further stimulus was inappropriate and likely impossible. The German Finance Ministry was able to leverage this disagreement so as to position itself on one side (which it perceived to be the correct side) of an ongoing debate.

Politicians from different nations and academics representing different schools of thought are currently split. Is it time to withdraw debt-financed stimulus programmes launched because of the economic crisis and get badly hit public budgets back on track? Or is the perceptible recovery still so fragile that we need more stimulus to keep the economy going? US economist Paul Krugman recently advocated the latter. He argued that savings measures such as those 
being planned by Germany were premature and jeopardised (global) economic recovery. His prescription: More stimulus financed by even more government debt. He said that if need be we have to run the risk of higher inflation. Numerous economists ... oppose this and defend the strategy also being pursued by Germany.

... further stimulus is superfluous, and at worst, even dangerous, especially in view of the risk of higher inflation. Against this background, Wolfgang Franz, the head of the economic advisers to the German Government, warns about putting off saving indefinitely in his Handelsblatt article. ... On the basis of empirical studies, economic expert Wolfgang Franz demonstrates that we can generally consider ourselves lucky if the state's financial deficit at least produces an equivalent increase in GDP. ... Conclusion: Another round of stimulus in an upturn is not worthwhile. der Finanzen, 2010

Whether the one or the other position was right, Germany could point to expert economic arguments supporting its advocacy of austerity. This became ever more important in the lead up to the G20 summit of June 2010. At the previous meeting, the gathered governments had reaffirmed their commitment to fiscal stimulus until the world economy showed clear signs of recovery. The United States, which wanted a strengthening of this affirmation and, if possible, a more concrete plan of action, recognized Germany as the country most likely to block action. Over the months leading up to the meeting, it persistently put indirect pressure on Germany, culminating in a letter from President Barack Obama, warning of the global economic risks of a premature withdrawal of fiscal stimulus programs. Germany proved unbending, warning pointedly for its part that "just as it would be dangerous to abruptly remove such support, governments should not become addicted to borrowing as a quick fix to stimulate demand" and opining that 
Behind the calls for us to pursue a more expansionary fiscal course lie two different approaches to economic policymaking on each side of the Atlantic. While US policymakers like to focus on short term corrective measures, we take the longer view and are, therefore, more preoccupied with the implications of excessive deficits and the dangers of high inflation [Schauble, 2010]

The United States (which was having domestic difficulty persuading Congress to pass a further stimulus package) lost. While the Wall Street Journal described the summit's conclusion as "a compromise between two competing visions of the international economy" represented by the US and Germany, it was clear which side had had to compromise more. The final communique noted that

Those countries with serious fiscal challenges need to accelerate the pace of consolidation. This should be combined with efforts to rebalance global demand to help ensure global growth continues on a sustainable path. ... We welcome the recent announcements by some countries to reduce their deficits in 2010 and strengthen their fiscal frameworks and institutions

watering down previous commitments and effectively ending any efforts to coordinate further fiscal stimulus policies at the international level.

As in 2008-2009, economic debates were asymmetric. Arguments among American economists still had a strong influence in Europe and elsewhere - harsh criticisms of the German government by Paul Krugman were politically important to an extent that would have been inconceivable had a German economist of similar stature criticized US policy. Ideas about fiscal policy were debated back and forth among a small group of elite economists. However, in contrast to the first period, these economists were joined in debate by a group who had not been directly involved the first time around - senior figures 
in the European Central Bank. These economists had sufficient expertise to stake out an alternative position; one which was much less friendly towards Keynesianism and activist fiscal policy. They also had direct leverage over European policy makers, especially after the Greek crisis, when European states began to debate how best to manage the interdependence between EMU members with very different approaches to fiscal management. Thus, the influence of American economists on European debate was weaker than it had been in the first round. Finally, they were able to turn to prominent external economists, such as Taylor and Alesina, to find support for their arguments.

The result was a structured dissensus rather than consensus within the expert community. On the one side, Keynesians (whether long-standing or recently converted) continued to make their arguments. On the other, an increasingly confident and mutually reinforcing group of economists made arguments for fiscal consolidation, and for economic austerity, where they believed it necessary to reassure markets.

This dissensus provided governments with far more room for maneuver. When confronted by a reiteration of the demand for stimulus, the German government was able to draw rhetorical resources from economists in the US and Europe who were unconvinced by the need for prolonged stimulus. This allowed it to resist US demands, and the creation of global norms about fiscal politics which it found uncongenial. Neither Germany nor other states who were unenthused by Keynesianism needed to make their own alternative perspective prevail. All they needed was a clash of perspectives, in which they could draw on the arguments of some experts to deflect the criticisms of others.

Again, expert consensus does not provide a complete explanation. Contingent factors, such as the travails of the eurozone provided Germany with additional rhetorical resources, while more traditional forms of bargaining power help explain Germany's current ability to dictate the terms of fiscal retrenchment to other member states. The European Central 
Bank possesses not only expertise, but direct power to shape financial markets. Even so, had expert dissensus not emerged, political actors would have found themselves substantially constrained. As in late 2008 and early 2009, the German government would have had to have pursued policy choices that were depicted by experts as profoundly mistaken, opening it up to political attack and the possible necessity of ignominious retreat.

\section{Conclusions}

In this article, we have made two major claims. First - that we can understand the creation of consensus (or dissensus) within an expert community as a process of contagion across that community. Second - that the appearance of consensus or dissensus within this community will determine whether ideas are, or not, politically influential.

The evidence seems to bear these arguments out. In 2008-2009, it was important that a relatively small number of 'star' economists, mostly based in the US, made vigorous arguments for Keynesianism. It was also important that some key figures who previously had not been favorably disposed to Keynesianism changed their minds. This helped propagate the idea of Keynesian stimulus to economists who otherwise would likely have been inoculated against it. Some of these economists - such as members of the Council of Economic Experts - played a key role in changing the field of debate within Germany and other European countries. Even if the actual consensus among economists was rather less solid than it appeared to outside observers, the appearance of an emerging consensus was what mattered. In 2010 in contrast, it mattered that there was a greater degree of disunity among economists in the US and within the IMF than there had been in the previous period. It also mattered that a new group of elite economists - those associated with the European Central Bank - had entered the fray. The debate was not nearly as one sided as it had been in the first instance. The contagion of the previous period in part reversed its 
course.

The appearance of consensus among experts is highly important in determining how their ideas affect policy actors. However, this appearance is a product of network topology and social pressures as much as, and in many cases more than, the kinds of processes of disinterested inquiry valued by scholars of epistemic communities. There are always likely to be doubters - the important question is whether these doubters' opinions are widely propagated in a publicly visible manner, or instead die on the vine. Where there is no apparent consensus, we may expect the effects of expert ideas on policy actors to be limited at best. They still may have a role in argument - but policy actors will have far greater freedom to pick and choose sides of the argument that they find convenient for their own purposes.

This has implications for how we think about the role of ideas in international relations. Most obviously, it suggests that the intricate micromechanisms through which ideas spread may sometimes be less important than gross social structures. Whether expert economists were deeply convinced, half-convinced, or not convinced at all by Keynesian ideas, did not matter as much as the external perception, in large part generated by patterns of propagation, that there had been a sea-change in the discipline. Strategic silences as well as Damascene conversions helped to perpetuate this perception. This points the scholarship of ideas in some new directions. The current literature on ideas is nearly entirely constructivist. It has been intimately shaped by a set of debates in which constructivists have pitted themselves against rationalists (whose arguments about e.g. human motivation and communication constructivists find to be uncompelling) and quantitative methods (against which constructivists often pit various forms of interpretivism). We agree with at least some of these criticisms - yet we also argue that ideas have many important aspects beyond the intimate processes of persuasion and convincing which constructivists typically 
focus on. Nor is interpretivism the only way in which we can come to grips with ideas. Exactly to the extent that ideas have causal force, we should be able to use a variety of tools of social science inquiry to draw inferences about the causal relations that they have with other aspects of the world. Here, by following Sperber [1996]'s materialist, and reductionist account of ideas we provide international relations scholars with a way to think about the spread of ideas that does not get bogged down in micro-debates about the circumstances under which we can or cannot say that one actor has sincerely persuaded another. Moreover, this way of thinking lends itself easily to quantitative analysis as scholars begin to gather appropriate datasets.

Finally, we return to the question posed at the beginning of this article, and by the special issue more generally. How do these arguments help us think better about the relationship between ideas and power in international financial orders? First, it helps us understand where consensus comes from, and the circumstances under which it is unlikely to arise. Specifically, it highlights how the success (or failure) of ideas to diffuse within a given expert community may have as much to do with power relations as with disinterested inquiry, bearing out the special issue's focus on the relationship between power and ideas. Some actors are more powerful than others, and may serve as gatekeepers within the expert community itself. Mapping out networks can provide a more precise understanding of these disparities. Equally, paying attention to the relationship between national concentrations of expertise and what the authors of the special issue term 'hegemonic power' may be highly fruitful. The predominance of US economists in international debates has consequences.

Second, our arguments provide some insights into the broader issues concerning global financial orders addressed in this special issue. They do not tell us whether the model laid out in the introduction, of a cycle between different models of economic order, punctuated by brief patterns of instability, is correct. Our findings are compatible with this broader 
account - it is entirely possible that the current structured dissensus will over time give way to a new consensus, as one approach to managing the economy builds a sufficient political coalition to support its introduction, and to protect it in its early stages. However, our findings are also compatible with a different interpretation. We have no warrant to conclude that instability and disagreement must eventually give way to agreement. It is just as possible that we are entering into a new global financial system which will be less driven by consensus than by continuing and ultimately irresolvable tensions between different and antithetical ways of ordering the economy, and consequent confusion and trench warfare. Such a world would pose extraordinary challenges to scholars of international political economy, who naturally prefer simplicity and elegance to bewildering complexity. But that is no reason to think that it could not come into being. 


\section{References}

Alberto F. Alesina and Silvia Ardagna. Large Changes in Fiscal policy: Taxes Versus Spending. NBER working paper, 2009.

Christopher S Allen. Monetary Union in Crisis: The European Union as a Neo-Liberal Construction, chapter "Ordo-Liberalism" Trumps Keynesianism: Economic Policy in the Federal Republic of Germany and the EU, pages 199-221. Palgrave, 2005.

Michael N. Barnett and Martha Finnemore. Rules for the world: International organizations in global politics. Cornell Univ Pr, 2004.

Robert J. Barro and Charles Redlick. Stimulus spending doesn't work. The Wall Street Journal, October 2009. URL http://online.wsj.com/article/ SB10001424052748704471504574440723298786310.html.

Olivier Blanchard, Giovanni Dell'Ariccia, and Paulo Mauro. Rethinking Macroeconomic Policy. IMF Research Department, Washington DC, 2010. URL http://www .imf .org/ external/pubs/ft/spn/2010/spn1003.pdf.

Alan S. Blinder. The Case Against the Case Against Discretionary Fiscal Policy. Number 100 in CEPS Working Papers. CEPS, 2004.

Mark Blyth. Great transformations: Economic ideas and institutional change in the twentieth century. Cambridge Univ Pr, 2002.

Mark Blyth. Structures do not come with an instruction sheet: Interests, ideas, and progress in political science. Perspective on Politics, 1(04):695-706, 2003.

Ana Rute Cardoso, Paolo Guimarães, and Klaus F. Zimmermann. Trends in Economic Research: An International Perspective. IZA Discussion Paper, 2010. 
Charli Carpenter. Vetting the Advocacy Agenda: Network Centrality and the Paradox of Weapons Norms. International Organization, 2010.

R.C. Carpenter. Studying issue (non)-adoption in transnational advocacy networks. International Organization, 61(03):643-667, 2007.

Jeffrey M. Chwieroth. Capital ideas: the IMF and the Rise of Financial Liberalization. Princeton University Press, 2009.

David C. Colander. The Making of an Economist, Redux. Princeton Univ Pr, 2007.

J.Bradford DeLong. Keynes \& Co have lost the Stimulus Argument. The Week, July 6:-, 2010. ISSN 0020-8183.

Bundesministerium der Finanzen. Borrow or Save Our Way Out of the Crisis? 2010. URL http://www.bundesfinanzministerium.de/nn_103442/EN/Topics/ Fiscal-policy/Articles/20100816-Borrow-save-way-out-crisis.html.

Sebastien Dullien. German Economists Have to Take Some Blame for Merkel's Slow Reaction. Eurozone Watch, 2008. URL http://www .euro-area.org/blog/?p=157.

Barry Eichengreen. In desperate economic times, grasp the fiscal nettle. http://www.guardian.co.uk/commentisfree/2008/oct/09/creditcrunch.economy, August 2008. URL http://www.guardian.co.uk/commentisfree/2008/oct/09/ creditcrunch.economy

Martin Feldstein. The retreat of Keynesian economics. The Public Interest, Summer 1981: 92-105, 1981. ISSN 0020-8183.

Martin Feldstein. Acceptance remarks, 2007 bradley prize. 2007. 
Marion Fourcade. The Construction of a Global Profession: The Transnationalization of Economics. AJS, 112(1):145-94, 2006.

Carsten Germi. Im gespräch: Stefan homburg: Rettungsschirm legt keim für nächste krise“ - wirtschafts- \& finanzkrise - wirtschaft. http://www.faz.net/s/Rub58241E4DF1B149538ABC24D0E82A6266/DoceED28DA1C7A4CE4EDF848726

2009. URL http://www.faz.net/s/Rub58241E4DF1B149538ABC24D0E82A6266/ Doc ED28DA1C7A4CE4EDF8487262C30695EFA ATpl Ecommon Scontent.html.

Chris Giles and Gillian Tett. Imf head in shock fiscal warning. The Financial Times, January 2008. URL http://www.ft.com/cms/s/0/ 106230b0-cd29-11dc-9b2b-000077b07658.html.

Peter Gourevitch. Politics in Hard Times: Comparative Responses to International Economic Crises. Cornell University Press, 1986.

Sanjeev Goyal, Marco Juri van der Leij, Jose Luis. Moraga-Gonzales, and C. Pecharroman. Economics: An Emerging Small World. Journal of Political Economy, 114(2):403-432, 2006. ISSN 0138-9130.

Emilie M. Hafner-Burton, Miles. Kahler, and Alexander H. Montgomery. Network Analysis for International Relations. International Organization, 63(03):559-592, 2009. ISSN 0020-8183.

Peter A. Hall. The political power of economic ideas: Keynesianism across nations. 1989.

Peter A. Hall. Policy paradigms, social learning, and the state: the case of economic policymaking in britain. Comparative politics, pages 275-296, 1993.

Hugh Heclo. Modern social politics in Britain and Sweden: From relief to income maintenance. Yale University Press New Haven, CT, 1974. 
Juan E. Iglesias and Carlos Pecharroman. Scaling the h-index for different scientific ISI fields. Scientometrics, 73(3):303-320, 2007. ISSN 0138-9130.

Johannes Lindvall. The Real But Limited Influence of Expert Ideas. World Politics, 61 (04):703-730, 2009. ISSN 0043-8871.

Ryan Lizza. Inside the Crisis: Larry Summers and the White House economics team. The New Yorker, October 12:-, 2009. ISSN 0020-8183.

N. Gregory Mankiw. The macroeconomist as scientist and engineer. The Journal of Economic Perspectives, pages 29-46, 2006.

González-Páramo, José Manuel. Monetary and fiscal policy interactions during the financial crisis, February 2010. URL http://www.ecb.int/press/key/date/2010/html/ sp100226.en.html.

Angela Merkel. Speech to the CDU annual conference, December 2008. URL http://www.stuttgart08.cdu.de/wp-content/uploads/2008/12/ 081201-rede-merkel-stbericht.pdf.

Stephen Nelson. The International Monetary Fund and the Spread of Neoliberal Policymakers in the Developing World. unpublished paper. ISBN 080148152X.

Stephen Nelson and Andrew Yeo. Ideational Explanations in International Relations: Old Problems and New Approaches.

Abraham L. Newman. Flight from Risk: Unified Germany and the Role of Beliefs in the European Response to the Financial Crisis. German Politics and Society, 28(2):151-164, 2010. 
M.E.J. Newman and J. Park. Why social networks are different from other types of networks. Physical Review E, 68(3):36122, 2003. ISSN 1550-2376.

Daniel H. Nexon and Thomas Wright. What's at stake in the american empire debate. American Political Science Review, 101(2):253, 2007.

Richard Posner. How i became a keynesian. The New Republic, September 2009. URL http://www.tnr.com/article/how-i-became-keynesian.

John G. Ruggie. International Regimes, Transactions, and Change: Embedded Liberalism in the Postwar Economic Order. International Organization, 36(02):379-415, 1982. ISSN 0020-8183.

Frankfurter Rundschau. Peter struck zu sachverstaendigenrat: Inkompetent und ueberfluessig. Frankfurter Rundschau.

Wolfgang Schauble. Maligned Germany is right to cut spending. The Financial Times, June 23:-, 2010.

David A. Siegel. Social Networks and Collective Action. American Journal of Political Science, 53(1):122-138, 2009. ISSN 1540-5907.

Kathryn Sikkink. Ideas and Institutions: Developmentalism in Argentina and Brazil. Ithaca: Cornell University Press, 1991.

Robert Skidelsky. Keynes: The Return of the Master. Public Affairs, 2009.

Dan Sperber. Explaining Culture: A Naturalistic Approach. Wiley-Blackwell, 1996. ISBN 0631200452 .

Ron Suskind. Confidence Men: Wall Street, Washington, and the Education of a President. HarperCollins, 2011. 
Jean-Claude Trichet. Stimulate No More - It Is Now Time for All to Tighten. The Financial Times, July 22:-, 2010.

Louis Uchitelle. Economists warm to government spending but debate its form. The New York Times, January 2009. ISSN 0362-4331. URL http://www.nytimes.com/2009/01/ 07/business/economy/07spend.html?_r=3\&ref=economy.

Philippe Urfalino. Apparent Consensus and Voting: Two Modes of Collective DecisionMaking. unpublished paper.

Alexander Von Neubacher and Michael Sauga. DER SPIEGEL 5/2009 - sind alle verrückt geworden? http://www.spiegel.de/spiegel/print/d-63806924.html, January 2009. URL http://www.spiegel.de/spiegel/print/d-63806924.html.

D.J. Watts and S.H. Strogatz. Collective dynamics of 'small-world'networks. Nature, 393 (6684):440-442, 1998. ISSN 0028-0836.

Duncan Watts. The collective dynamics of belief. Paper available online at http://cdg. columbia. edu/uploads/papers, 2007. 